DOI: $\square$ https://doi.org/10.15407/techned2020.05.026

\title{
TWO-INVERTER-BASED PHOTOVOLTAIC INSTALLATION ADJUSTED BY THE MODIFIED SCHEME OF SPACE-VECTOR MODULATION
}

Journal

Publisher

ISSN

Issue

Pages
Tekhnichna elektrodynamika

Institute of Electrodynamics National Academy of Science of Ukraine 1607-7970 (print), 2218-1903 (online)

No 5, 2020 (September/October)

$26-30$

\author{
Authors \\ V. Oleschuk ${ }^{*}$, Dr.Sc., V. Ermuratskii, Dr.Sc. \\ Institute of Power Engineering of Moldova, \\ Academy Str. 5, Kishinau, MD-2028, Moldova, \\ e-mail: oleschukv@hotmail.com \\ * ORCID ID : https://orcid.org/0000-0002-7413-4867
}

\begin{abstract}
Algorithms of synchronous one-stage modulation have been modified and disseminated for adjustment of two two-level inverters of transformer-based photovoltaic installation with specific double-delta configuration of inverter-side windings of power transformer. Modified algorithms of synchronous space-vector modulation, applied for control of inverters of PV system with specialized connection of windings of power transformer, assure improved spectral composition of winding voltages of transformer, characterized by the lacking in its spectra of even harmonics and undesirable subharmonics for any control modes and regimes of operation of system. Refer ences 9 , figures 6 , table 1 .
\end{abstract}

Key words: voltage source inverter, photovoltaic panels and arrays, multi-winding transformer, modulation strategy. 
Accepted: 01.06 .2020

Published: 25.08.2020

\section{References}

1. Aiello M., Cataliotti A., Favuzza S., Graditi G. Theoretical and experimental comparison of Total Harmonic Distortion factors for the evaluation of harmonic and interharmonic pollution of grid-connected photovoltaic systems. IEEE Transaction on Power Delivery. 2006. Vol. 21. No 3. Pp. 1390-1397.

DOI:

s://doi.org/10.1109/TPWRD.2005.860231

http

2. Grandi G., Rossi C., Ostojic D., Casadei D. A new multilevel conversion structure for grid-connected PV applications. IEEE Transaction on Industrial Electronics. 2009. Vol. 56. No 11. Pp. 4416-4426.

DOI:

https://doi.org/10.1109/TIE.2009.2029587

3. Shavelkin A., Shvedchykova I. Multifunctional converter for single-phase combined power supply systems for local objects with a photovoltaic solar battery. Tekhnichna Electrodynamika. 2018. No 5. Pp. 92-95. DOI:

https://doi.org/10.15407/techned2018.05.092

4. Pires V.F., Cordeiro A., Foito D., Silva J.F. Three-phase multilevel inverter for grid-connected distributed photovoltaic systems based in three three-phase two-level inverters. Solar Energy. 2018. Vol. 174. Pp. 1026-1034.

DOI:

https://doi.org/10.1016/j.solener.2018.09.083

5. Shavelkin A.A. Improvement of the structure for the current control loop with the use of PWM for the grid inverter of the combined power supply system. Tekhnichna Electrodynamika. 2019. No 3. Pp. 37-45. (Ukr) DOI:

https://doi.org/10.15407/techned2019.03.037

6. Park Y., Ohn S., Sul S-K. Multi-level operation with two-level converters through a double-delta source connected transformer. Journal of Power Electronics. 2014. Vol. 14. No 6. Pp. 1093-1099. DOI: https://doi.org/10.6113/JPE.2014.14.6.1093

7. Blaabjerg F., Oleschuk V., Lungeanu F. Synchronization of output voltage waveforms in three-phase inverters for induction motor drives. IEEE-IEEJ Power Conversion Conference (PCC'2002). Osaka, Japan, 2002. Pp. 528-533.

8. Oleschuk V., Griva G., Profumo F., Tenconi A. Synchronized PWM control of symmetrical six-phase drives. IEEE International Conference on Power Electronics(ICPE'2007). Daegy, Korea, 2007. Pp. 147-152.

DOI:

https://doi.org/10.1109/ICPE.2007.4692366

9. Oleschuk V., Barrero F. Standard and non-standard approaches for voltage synchronization 
of drive inverters with space-vector PWM: A survey. International Review of Electrical Engineering 2014. Vol. 9. No 4. Pp.

688-707.

DOI: https://doi.org/

10.15866/iree.v9i4.1852

PDF

@๑๑०

This work is licensed under a Creative Commons Attribution-NonCommercial-NoDerivatives $\underline{4.0}$ International License 